\title{
Behavioral and physiological responses to PSP toxins in Mya arenaria populations in relation to previous exposure to red tides
}

\author{
Scott P. MacQuarrie ${ }^{1,2, *}$, V. Monica Bricelj ${ }^{1,3}$ \\ ${ }^{1}$ National Research Council, Institute for Marine Biosciences, 1411 Oxford Street, Halifax, Nova Scotia B3H 3Z1, Canada \\ ${ }^{2}$ Present address: MacQuarrie Research Consultants, 1142 Ketch Harbour Road, Ketch Harbour, Nova Scotia B3V 1K6, Canada \\ ${ }^{3}$ Present address: Institute of Marine and Coastal Sciences, Rutgers University, New Brunswick, New Jersey 08901, USA
}

\begin{abstract}
Paralytic shellfish poisoning (PSP) poses a severe human health risk worldwide and can also adversely affect bivalve populations. This study investigates the intraspecific variation in sensitivity to paralytic shellfish toxins (PSTs) and in toxin accumulation capacity between 2 populations with contrasting histories of PSP in the softshell clam Mya arenaria, a species widely distributed in Atlantic North America. We determine the magnitude and potential ecological consequences of intrinsic variation in toxin susceptibility in $M$. arenaria, known to have a genetic basis, and the implications for prediction and management of PSTs in regions affected or threatened by PSP expansion. Burrowing, feeding, oxygen consumption $\left(\mathrm{VO}_{2}\right)$, toxin uptake and survival of 2 test populations were compared during 2 to $3 \mathrm{wk}$ of laboratory exposure to a high-toxicity Alexandrium tamarense strain. Most clams from Lepreau Basin, Bay of Fundy (BF), an area with a long-term history of annual PSP events, exhibited high resistance measured by these parameters, relative to naïve clams from the Lawrencetown Estuary (LE). These were highly sensitive to PSTs, as reflected in significantly reduced clearance and $\mathrm{VO}_{2}$ rates; they also failed to acclimate to the presence of toxins. BF clams attained significantly higher (up to 10 -fold) tissue toxicities than LE clams. Toxicity of individual clams from the 2 populations varied up to 40 -fold under the same experimental conditions. Toxininduced mortalities were consistently higher among LE clams (up to $30 \%$ ) compared to BF clams ( 2 to $8 \%$ ). Our findings support the hypothesis that red tides result in natural selection for resistance to PSTs in natural populations.
\end{abstract}

KEY WORDS: Paralytic shellfish toxins $\cdot$ Softshell clams $\cdot$ Mya arenaria $\cdot$ Burrowing $\cdot$ Ecophysiology Alexandrium tamarense

Resale or republication not permitted without written consent of the publisher

\section{INTRODUCTION}

Paralytic shellfish poisoning (PSP) poses a severe human health risk worldwide and toxic events have been increasing globally in frequency, intensity and geographic spread in past decades (Hallegraeff 2003). Severe economic impacts are associated with PSP events ranging from decreased shellfish consumption to indefinite bans on shellfish harvest, as is the case with the butter clam Saxidomus giganteus fishery in Alaska where clams remain toxic year-round. An extensive bloom along the New England coast in 2005 led to shellfish harvest closures from central Maine to
Martha's Vineyard, Massachusetts, including 40000 $\mathrm{km}^{2}$ of offshore federal waters, prompting the governors of both Maine and Massachusetts to declare a state of emergency (Anderson et al. 2005). The economic losses from this PSP event are reported to exceed \$15 million in Massachusetts alone (Anderson et al. 2005). Outbreaks of PSP in North America are caused by toxigenic, unicellular or chain-forming dinoflagellates 20 to $50 \mu \mathrm{m}$ in size from the Alexandrium species complex. The species responsible for PSP on the Atlantic coast of North America are $A$. tamarense and $A$. fundyense, which range in distribution from the Gulf of St. Lawrence to Long Island, New 
York (Maranda et al. 1985), whereas A. catenella is the source of paralytic shellfish toxins (PSTs) on the Pacific coast of North America, occurring from Alaska to southern California (Taylor 1984).

Bivalves exhibit marked interspecific variation in response to PSTs as measured by various physiological indices, such as in vitro nerve sensitivity, feeding rates and toxin kinetics (toxin uptake and detoxification rates), and thus toxicities attained (reviewed by Bricelj \& Shumway 1998). The capacity for toxin accumulation is species-specific and is not related to taxonomic status. For example, it can vary considerably among oyster species (Ostreidae) (Shumway et al. 1990). Twarog et al. (1972) ranked PSP toxin sensitivity in several bivalve species from Atlantic North America by subjecting isolated nerves to increasing concentrations of purified saxitoxin (STX) and measuring the effects on the action potential. They found a 1000-fold difference in the STX concentration necessary to block the action potential among the 7 species tested. The blue mussel Mytilus edulis was the most resistant to STX, showing no signs of nerve block at the highest concentration tested $\left(10^{-4} \mathrm{~g} \mathrm{ml}^{-1}, 334 \mu \mathrm{M}\right)$, whereas the eastern oyster Crassostrea virginica was extremely sensitive to STX, with nerve blocking at $10^{-7} \mathrm{~g} \mathrm{STX} \mathrm{ml}^{-1}$ $(0.334 \mu \mathrm{M})$. The softshell clam Mya arenaria (collected from Woods Hole, Massachusetts) was ranked as having intermediate sensitivity, with full nerve block occurring at $10^{-5} \mathrm{~g} \mathrm{STX} \mathrm{ml}^{-1}(33.4 \mu \mathrm{M})$. It is important to note that the present study was conducted prior to the first documented occurrence of PSP in southern New England in 1972 (B. Twarog, University of Maine, pers. comm.), which resulted from southward transport of dinoflagellate cysts by a hurricane. Kvitek (1993) confirmed the intermediate sensitivity (nerve block at $5 \times 10^{-6} \mathrm{~g} \mathrm{STX} \mathrm{ml}^{-1}$ ) from a west coast (Carr Inlet, Washington), non-native population of $M$. arenaria. However, both studies used very small sample sizes (n = 3) for their nerve assays and were thus unable to detect individual variation within the test population.

Variation among individuals in response to PSP toxin exposure within a population of Mya arenaria was demonstrated by Bricelj et al. (1996) and Laby (1997). During toxification experiments these authors found that 7 to $31 \%$ of clams from a population from Mount Sinai Harbor, Long Island Sound, New York, were insensitive to the effects of toxins as determined by a burrowing index, which measures the ability of $M$. arenaria to reburrow in sediments following short-term ( $\sim 6$ to $24 \mathrm{~h}$ ) exposure to toxic Alexandrium cells. The burrowing index allows rapid and non-destructive characterization of PST sensitivity of individuals in large samples. Burrowing incapacitation is reversible following removal of clams from the toxin source. Bricelj et al. (2004) used the burrowing index to char- acterize the toxin sensitivity of $M$. arenaria populations along the east coast of North America and generally found a good correlation between resistance and the history of toxin exposure. Thus resistant clams were dominant in populations with a history of PSP outbreaks, whereas sensitive clams were prevalent in areas unaffected by PSP. They also found good agreement between resistance measured by the in vitro nerve assay and the burrowing index for 4 Atlantic $M$. arenaria populations. These results supported Twarog's (1974) previously untested hypothesis that bivalve populations recurrently affected by PSP outbreaks might undergo genetic adaptation to toxins through reduced fitness and natural selection against more sensitive individuals.

Our previous work described marked differences in the STX concentration necessary to elicit a nerve block response between representative Mya arenaria from 2 Atlantic populations with contrasting histories of PSP and attributed these differences to a point mutation in the sodium $\left(\mathrm{Na}^{+}\right)$channel gene sequence of resistant clams that greatly reduced binding affinity to STX (Bricelj et al. 2005). The present study was designed to determine the lethal and sublethal effects of $\sim 2 \mathrm{wk}$ laboratory exposure of $M$. arenaria from these 2 populations. Key questions addressed by the present research include: (1) Does long-term history of exposure of a population to PSTs affect the clams' sensitivity to toxins, as measured by clearance rate (CR) on toxic cells, oxygen consumption $\left(\mathrm{VO}_{2}\right)$ as a measure of metabolic cost and toxin accumulation rates? (2) Do sensitive individuals acclimate feeding and burrowing responses to toxins after several weeks of laboratory toxification? Hence, can physiological acclimation contribute to toxin resistance? (3) Are PSTs lethal to sensitive clams, and if so, what is the timing of toxin-induced mortalities? As a result of this work, a molecular basis for resistance to PSTs in $M$. arenaria was demonstrated by the identification of a naturally occurring point mutation in Domain II of the $\mathrm{Na}^{+}$channel gene responsible for a 1000-fold increase in STX-binding affinity in resistant clams (Bricelj et al. 2005, Connell et al. 2007). From the results of the present study the potential fitness consequences of exposure of sensitive softshell clams to a highly toxic bloom of Alexandrium tamarense in the natural environment can be inferred.

\section{MATERIALS AND METHODS}

Mya arenaria collection and maintenance. $M$. arenaria were collected from the mid-intertidal region to ensure similar immersion time among individuals sampled, using a traditional clam hack, from 2 sites: (1) Lepreau Basin, Bay of Fundy, New Brunswick (BF) 
and (2) Lawrencetown River Estuary, Nova Scotia (LE). These sites were chosen because they differ in their long-term toxin exposure histories. Records of annual, recurrent PST levels in $M$. arenaria and Mytilus edulis are available for Lepreau Basin since 1943, with a historical maximum of $9000 \mu \mathrm{g}$ STXeq $100 \mathrm{~g}^{-1}$ reported in 1976 (Martin \& Richard 1996). The Lawrencetown River Estuary was chosen as representative of sites where shellfish have not been previously exposed to PSP. There is no record of harvest closures due to PSP in the area, and samples from a nearby site (Chezzetcook, Nova Scotia) have never exceeded the regulatory limit of $80 \mu \mathrm{g}$ STXeq $100 \mathrm{~g}^{-1}$ tissues (B. Moore pers. comm.). Only juvenile clams 33 to $47 \mathrm{~mm}$ in shell length (SL) were collected for the present study and transported in coolers to the National Research Council's (NRC) Marine Research Station (MRS), Ketch Harbour, Nova Scotia. Juveniles, which are more active, faster burrowers (Emerson et al. 1990), were used in all experiments to minimize the confounding effects of reproductive state as well as reduce the amount of cultured toxic algae necessary for experiments. Clams were collected in early spring prior to bloom initiation or in late fall after they had sufficient time to depurate toxins. The absence of detectable PSP levels in tissues was confirmed at each time.

Prior to experimentation, clams were held in flowthrough raceways containing $10 \mathrm{~cm}$ of washed coarse sediment (sand) with a flow of $\sim 101 \mathrm{~min}^{-1}$ of ambient, unfiltered seawater (salinity $\approx 30 \%$ ). After several days under these conditions, the temperature was slowly increased $\left(\sim 1^{\circ} \mathrm{C} \mathrm{d}^{-1}\right)$ to $16^{\circ} \mathrm{C}$. Clams were acclimated at this temperature for a minimum of $3 \mathrm{wk}$ (typically 3 to $12 \mathrm{wk}$ ). Ambient seawater was supplemented with the continuous addition of the diatom Thalassiosira weissflogii via a peristaltic pump.

Algal culture. The toxigenic dinoflagellate Alexandrium tamarense (strain PR18b isolated from the Estuary of the Gulf of St. Lawrence, Canada; $35 \mu \mathrm{m}$ mean equivalent spherical diameter, ESD) was used in all experiments due to its high cellular toxicity. $A$. tamarense was cultured using a modified L1 medium formulation with the addition of $\mathrm{NH}_{4} \mathrm{Cl}$ at a final concentration of $5 \times 10^{-5} \mathrm{M}$ (Guillard \& Hargraves 1993) at $16^{\circ} \mathrm{C}$ with a $14 \mathrm{~h}: 10 \mathrm{~h}$ light:dark cycle $\left(146 \mu \mathrm{mol} \mathrm{s}{ }^{-1} \mathrm{~m}^{-2}\right.$ irradiance). Non-axenic, dinoflagellate cultures for Expt I were batch-cultured in 201 plastic carboys filled with $0.22 \mu \mathrm{m}$ cartridge-filtered, autoclaved seawater with gentle aeration, in a temperature-controlled environmental chamber. Those used in Expt II were cultured under semi-continuous conditions in a 2001 photobioreactor with $\mathrm{pH}$ and temperature control (664 $\mu \mathrm{mol} \mathrm{s} \mathrm{s}^{-1} \mathrm{~m}^{-2}$ irradiance) (Bauder et al. 2001). All cultures used in experiments were harvested in late exponential growth phase.
Thalassiosira weissflogii (12 $\mu \mathrm{m}$ mean ESD) was used as a nontoxic control alga in Expt II and during acclimation. This diatom was cultured in a $200 \mathrm{l}$ photobioreactor at $20^{\circ} \mathrm{C}$ with continuous light (664 $\mu \mathrm{mol} \mathrm{s}{ }^{-1}$ $\mathrm{m}^{-2}$ irradiance) using a commercially prepared (Fritz) F/2 medium formulation (Guillard \& Ryther 1962).

Toxin analysis. Duplicate samples of experimental Alexandrium tamarense cultures were collected for toxin analysis to determine cell toxicity (pg STXeq $\mathrm{cell}^{-1}$ ) and toxin composition. A predetermined culture volume was retained on a $20 \mu \mathrm{m}$ sieve to yield $1 \times 10^{6}$ cells for toxin extraction in 0.03M acetic acid (HOAc) following methods described in Bricelj et al. (1990). Mya arenaria were individually sampled and dissected into 2 tissue pools for toxin analysis: (1) visceral mass (including the digestive gland, stomach complex and gonadal tissues) and (2) other (remaining) tissues including gills, mantle, foot, adductor muscles and siphons. Wet weight (WW) of tissue pools, SL, as well as foot and siphon response to stimuli, of each clam were recorded. Tissues were immediately frozen in liquid $\mathrm{N}_{2}$ and stored at $-80^{\circ} \mathrm{C}$. Toxins were extracted from lyophilized tissues in 0.1M HOAc following previously described methods (Bricelj et al. 1990). Total body toxicity was calculated from the toxicity of individual tissue pools and their contribution to total body tissue weight, thus allowing comparisons between experimental and field toxicity data.

Toxin analysis of dinoflagellate and clam tissue extracts were performed by reverse-phase, ion-pair, high-performance liquid chromatography with postcolumn derivatization and fluorescence detection (HPLC-FD) according to the methods of Oshima (1995) with minor modifications. Three sample injections are required to quantify each of the 3 toxin groups: (1) STX, decarbamoyl saxitoxin (dcSTX) and neosaxitoxin (NEO); (2) N-sulfocarbamoyl C and B toxins and (3) gonyautoxins (GTXs) and decarbamoyl gonyautoxins (dcGTXs). Calibration toxin standards were obtained from IMB/NRC's Certified Reference Materials Program (CRMP), with the exception of dcGTX2\&3 and C1\&2. These toxins were quantified using toxin solutions provided by Maurice Laycock (IMB, NRC), which were checked at high concentration against the CRMP STX solution using capillary electrophoresis with UV detection. Toxicities were converted to saxitoxin equivalent units (STXeq) based on a conversion factor of $0.23 \mu \mathrm{g}$ STXeq $\mathrm{MU}^{-1}$ (Cembella et al. 1993) using relative potency values of individual toxins (MU $\mu_{m o l e}{ }^{-1}$ ) derived from the mouse bioassay by Oshima (1995).

Experimental setup. All experimental systems were set up in a walk-in, temperature-controlled environmental chamber at $16^{\circ} \mathrm{C}$. Clams were held in $160 \mathrm{l}$ glass aquaria $(80 \mathrm{~cm} \mathrm{~L} \times 40 \mathrm{~cm} \mathrm{~W} \times 33 \mathrm{~cm} \mathrm{H})$ with 
$10 \mathrm{~cm}$ of washed, coarse sediment and $140 \mathrm{l}$ of $0.5 \mu \mathrm{m}$ cartridge-filtered seawater (30\%), which was replaced every 2 to $3 \mathrm{~d}$ to minimize waste buildup. Each aquarium was fitted with 2 external, low-pressure pumps (Super King, Danner Mfg.) (placed at opposite ends) in order to keep the water oxygenated and algal cells in suspension.

The algal culture was continuously delivered via a multi-channel peristaltic pump (Masterflex console drive) from a stock reservoir at a rate necessary to balance consumption and maintain the desired treatment concentration. An algal concentration (Expts I \& II) of 100 Alexandrium tamarense cells $\mathrm{ml}^{-1}$ was chosen to simulate bloom levels known to occur in the BF (Martin et al. 1998), whereas an approximately equivalent biovolume concentration (2000 cells $\mathrm{ml}^{-1}$ ) of Thalassiosira weissflogii was used in the nontoxic control treatment (Expt II). Cell concentrations in the tank were determined in duplicate twice a day, morning and afternoon, using a Coulter Counter Multisizer particle counter (model IIe) fitted with a $140 \mu \mathrm{m}$ aperture, and periodically confirmed by light microscopy (cell densities determined using the 2 methods showed good linear correlation $\left[\mathrm{r}^{2}=0.98\right]$, with an average difference of only $10 \%$ ). Addition of algal culture was adjusted accordingly to maintain this concentration.

Burrowing response. The ability to re-burrow in sediment was used as a behavioral measure of the sensitivity of Mya arenaria to PSTs. Clams were removed from the sediment, redistributed on the sediment surface and allowed to burrow without interference for $2 \mathrm{~h}$, a period of time determined to be adequate for burial for clams of that size based on previous studies (Bricelj et al. 1996, Emerson et al. 1990). At the end of $2 \mathrm{~h}, \mathrm{M}$. arenaria with their umbo below the sediment surface were counted as burrowed, and burrowing was expressed as a percentage of the total number of clams in the trial. The time required for burrowing of individual clams was also determined during Expt I. At the end of the trial, clams that failed to burrow during the trial were repositioned vertically in the sediment to maintain their normal feeding position.

Physiological rate measures. Custom-designed chambers were used to house individual Mya arenaria, allowing burrowing and acclimation in sediment prior to determination of physiological rates $\left(\mathrm{CR}\right.$ and $\left.\mathrm{VO}_{2}\right)$. Acrylic chambers were constructed based on an earlier design (Lewis 1996, Lewis \& Cerrato 1997) comprised of a measurement chamber top and a sediment core bottom. The latter contained $15 \mathrm{~cm}$ of washed sediment and was held overnight in the treatment tank allowing clams to burrow and resume normal physiological functions. Prior to conducting physiological rate measurements, the chamber bottom was fitted to the chamber top $(260 \mathrm{ml})$ with an air- and watertight O- ring seal. The chamber top had inflow, outflow, sampling and oxygen probe ports (see MacQuarrie [2002] for a schematic). The chamber contents were mixed during trials using a $1 \mathrm{~cm}$ stir bar held in place at the top of the chamber by a large horseshoe magnet mounted on the outside of the chamber. The magnet was suspended from an $18 \mathrm{~V}$ electric hobby motor (Radio Shack) and controlled by a model train voltage regulator (PowerRail 1300). The treatment suspension was gravity fed from a head tank to the chamber assembly via a stopcock manifold. Outflow from the chamber was returned to the head tank with a peristaltic pump (Masterflex) to maintain constant head pressure and flow to the chambers. The head tank was mixed by aeration to ensure a homogeneous suspension. Clams were acclimated in this system and to the treatment suspension under flow-through conditions for 2 to $3 \mathrm{~h}$ prior to conducting physiological rate measurements. Only clams with siphons exposed at the sediment surface for the duration of the trial were included in these measurements.

Individual CR was determined using the closed system method described by Coughlan (1969), where: $\mathrm{CR}=\left[\ln \left(C_{\mathrm{i}} / C_{\mathrm{f}}\right)\right] \cdot V / t$. Initial $\left(C_{\mathrm{i}}\right)$ and final $\left(C_{\mathrm{f}}\right)$ suspension samples were taken from each of the chambers immediately prior to turning off the flow from the head tank at the stopcock manifold and at the end of the incubation period respectively. Clams were allowed to feed during the incubation period $(t)$ previously determined to ensure adequate removal ( 20 to $30 \%$ depletion). Cell counts were determined in duplicate or triplicate with an electronic particle counter as previously described. The seawater volume $(V)$ of each chamber was measured at the end of each trial.

$\mathrm{VO}_{2}$ rates were determined using a Strathkelvin 6channel respirometer (model 928) connected to a Toshiba Tectra 8000 portable computer with a microcathode oxygen electrode (model 1302, $\mathrm{VO}_{2}$ ca. 0.5 to $3 \times 10^{-10} \mathrm{mg} \mathrm{O}_{2} \mathrm{~min}^{-1}$ ) placed in each of the chambers. Oxygen probes were calibrated for 0 and $100 \%$ saturation with a $2 \%$ sodium sulfite solution and with oxygen-saturated filtered seawater at $16^{\circ} \mathrm{C}$, respectively. The incubation period allowed reduction of the dissolved oxygen concentration to $\geq 70 \%$ saturation. Oxygen depletion curves were fitted with linear regression equations to determine the $\mathrm{VO}_{2}$. Values were corrected for $\mathrm{VO}_{2}$ due to sediment microfauna, bacteria and/or algae determined for a control chamber with no clam present. $\mathrm{VO}_{2}$ rates were expressed on a weightspecific basis as the range of clam sizes was relatively small (1.24 to $3.15 \mathrm{~g}$ soft tissue WW).

Experimental design. Expt I-burrowing, feeding and toxin uptake rates: Mya arenaria from the 2 source populations were exposed to toxic Alexandrium tamarense (100 cells ml $\mathrm{ml}^{-1}$ ) for $15 \mathrm{~d}$ in two $160 \mathrm{l}$ aquaria, one 
(Tank 1) used for repeated burrowing trials, the other (Tank 2) for acclimation of clams used in feeding trials and sampling for determination of toxin accumulation rates. The burrowing trial tank contained numbered $M$. arenaria to allow tracking of individual response over time ( $\mathrm{n}=50$ for each of the BF and LE populations) yielding a tank stocking density of 312 clams $\mathrm{m}^{-2}$. Burrowing trials ( $\%$ burrowed after $2 \mathrm{~h}$ ) were conducted in the same tank (Tank 2) in which the clams were held after $24 \mathrm{~h}, 3 \mathrm{~d}, 9 \mathrm{~d}$ and $13 \mathrm{~d}$ of exposure using the same numbered clams for each trial. Clams for CR measurements were held in the feeding chamber bases and transferred to the physiological rate measurement system to determine feeding rates. CR measurements ( $\mathrm{n}=5$ clams) were carried out after $24 \mathrm{~h}, 7 \mathrm{~d}$ and $14 \mathrm{~d}$ of toxin exposure. Clams ( $\mathrm{n}=40$ of each population, BF and LE) were held separately in a section of the tank separated by a plastic mesh divider and sampled for individual toxicity ( $\mathrm{n}=5$ per population) every $2 \mathrm{~d}$ in order to determine toxin accumulation rates for each population. At the end of the experiment, $M$. arenaria used in feeding trials were also sampled for toxicity to correlate individual CR with tissue toxicity. The tank was monitored visually every $2 \mathrm{~d}$ for mortality, and any dead clams were removed. Tank replication was not possible due to the large amount of toxic algae required over $2 \mathrm{wk}$, but clams from the 2 source populations were exposed to a common, wellmixed suspension as verified in the experimental setup by preliminary trials. Toxicity patterns for both test populations were again obtained in a sequential experiment (Expt II below), which used duplicate tanks.

Expt II-Oxygen consumption and survival rates: Clams from the 2 test populations were exposed to 2 algal treatments (toxic and nontoxic or control) using 2 replicate tanks per treatment for $18 \mathrm{~d}$. Clams in Treatment 1 were exposed to bloom levels of Alexandrium tamarense (100 cells $\left.\mathrm{ml}^{-1}\right)$, and those in Treatment 2 were fed the nontoxic diatom Thalassiosira weissflogii (2000 cells ml ${ }^{-1}$ ). Clams from both populations were color coded and randomly mixed prior to introduction in each tank. Mya arenaria ( $\mathrm{n}=50$ from each population) were placed in one-half of each of the 4 tanks (Tanks 1 \& 2: toxified tanks; Tanks 3 \& 4: control tanks) (stocking density $=625$ clams $\mathrm{m}^{-2}$ ). Characterization of $M$. arenaria toxin sensitivity after $24 \mathrm{~h}$ exposure was conducted in the toxic tanks using the burrowing index (Bricelj et al. 2004), and each clam was identified as either sensitive or resistant with a mark on the shell. Mortalities were determined by removing all clams from the sediment at $2 \mathrm{~d}$ intervals, at which point dead clams were removed and their SL recorded; live clams were reintroduced to the sediment in an upright, normal feeding position.
Clams ( $\mathrm{n}=9$ per tank for the toxic treatment to compensate for any losses due to mortality, $n=6$ for the nontoxic treatment) used for aerobic metabolic rate measurements were individually numbered and segregated at opposite ends of the tanks. Measurements of $\mathrm{VO}_{2}$ for the treatment group were conducted at 2, 9 and $18 \mathrm{~d}$ of exposure; at each time clams from both populations were removed from the tanks and placed in the chamber assembly for overnight acclimation in the physiological rate measurement system under flow-through conditions. $\mathrm{VO}_{2}$ trials for the control group fed Thalassiosira weissflogii were conducted the day following the toxified trials due to the time constraints involved in obtaining these measurements simultaneously and were thus always offset by $1 \mathrm{~d}$. At the end of the trial, clams were returned to their respective tanks until the next trial. Clams were removed from the toxified tanks for individual toxin analysis after 2, 5, 8, 12 and $18 \mathrm{~d}$ of exposure as previously described. Clams used for $\mathrm{VO}_{2}$ measurements were also sampled for toxin analysis at the end of the experiment.

Statistical analysis. All statistical analysis was performed using the SYSTAT 8.0 (SPSS) software. A 2way ANOVA repeated measures design allowed comparisons of feeding rates for each population over the duration of the experiment. The 2 populations were compared for each trial using planned comparisons. A 2-way ANOVA was used to compare toxicities for the 2 populations over time. Comparisons of $\mathrm{VO}_{2}$ between populations over exposure time were made with a repeated measures 2-way ANOVA. All statistical tests were performed as 2-tailed tests.

\section{RESULTS}

\section{Algal toxicity and toxin composition}

Algal concentrations were very similar between treatment tanks and constant throughout the toxification period in Expt I (Tank 1, mean = $103 \mathrm{cells} \mathrm{m}^{-1}$, $\mathrm{SE}=3.4$; Tank $2=101$ cells $\mathrm{ml}^{-1}, \mathrm{SE}=3.3$ ). Cultures were harvested in late exponential growth phase 10 to $14 \mathrm{~d}$ from inoculation at a cell density of ca. 9000 to 13000 cells $\mathrm{ml}^{-1}$. Algal delivery rate by peristaltic pump averaged 70000 and 47000 cells $\mathrm{min}^{-1}$ for Tanks 1 and 2, respectively, in order to maintain the desired treatment concentration. Cell toxicity of Alexandrium tamarense (strain PR18b) cultures also remained relatively constant over time, averaging 60.7 pg STXeq cell ${ }^{-1}(\mathrm{SE}=2.6)$. Percent molar toxin composition of $A$. tamarense (strain PR18b) remained relatively constant over the experimental period. The $\mathrm{N}$-sulfocarbamoyl toxin, C2, was the highest contribu- 
Table 1. Percent Mya arenaria molar toxin composition $\left(\% \mathrm{M}_{i}\right.$ mean $\left.\pm \mathrm{SE}\right)$ of Alexandrium tamarense cells and clam tissues from the 2 test populations (Expt I) averaged over the $15 \mathrm{~d}$ exposure period (only toxins present at levels $>1 \%$ are included). - non-detectable

\begin{tabular}{|c|c|c|c|c|c|}
\hline & $\mathrm{C} 1+2$ & $\mathrm{GTX}_{3}$ & $\mathrm{GTX}_{2}$ & NEO & STX \\
\hline $\begin{array}{l}\text { A. tamarense } \\
\text { (PR18b) }\end{array}$ & $66.9 \pm 0.8$ & $2.6 \pm 0.1$ & - & $22.6 \pm 0.5$ & $7.6 \pm 0.6$ \\
\hline \multicolumn{6}{|c|}{ Lepreau Basin (BF) } \\
\hline Viscera & $68.3 \pm 0.9$ & $2.6 \pm 0.3$ & - & $18.9 \pm 1.1$ & $8.7 \pm 0.4$ \\
\hline Other tissues & $62.9 \pm 0.4$ & $3.3 \pm 0.4$ & $1.5 \pm 0.3$ & $22.5 \pm 0.4$ & $9.2 \pm 0.4$ \\
\hline \multicolumn{6}{|c|}{ Lawrencetown Estuary (LE) } \\
\hline Viscera & $67.4 \pm 0.6$ & $2.9 \pm 0.2$ & - & $16.5 \pm 1.1$ & $12.1 \pm 1.1$ \\
\hline Other tissues & $56.5 \pm 1.9$ & $3.6 \pm 0.5$ & $1.6 \pm 0.3$ & $25.9 \pm 1.4$ & $12.1 \pm 1.2$ \\
\hline
\end{tabular}

for Tank 3 and 1748 cells $\mathrm{ml}^{-1}$ (SE = 69.2) for Tank 4. Toxin composition of A. tamarense (strain PR18b) was similar to that of cultures used in Expt I except for the presence of a small amount of GTX4 (data not shown).

\section{Burrowing response}

Mya arenaria from the LE population were adversely affected by PSTs after only $7 \mathrm{~h}$ of toxin exposure, as evidenced by limp, non-retractable siphons (upon aerial exposure or tactile stimulation) and inability to close tor (66 to $69 \%$ ) to total toxin concentration, followed by GTX3, NEO and STX; trace amounts of GTX4 and dcGTX3 were also present (Table 1). However because of the low potency of $\mathrm{C} 2$, the bulk of the toxicity (63 to $77 \%$ ) was due to the highly potent NEO and STX derivatives.

In Expt II, Alexandrium tamarense (strain PR18b) cultured in the photobioreactor attained a $67 \%$ higher mean toxicity (98.1 pg STXeq cell ${ }^{-1}$ ) per cell compared to carboy cultures used in Expt I (60.7 pg STXeq cell ${ }^{-1}$ ). Cellular toxicity of cultures remained relatively constant over the 3 wk experiment except on Day 13 when carboy cultures were used due to limited availability of culture from the photobioreactor. Algal cell density in toxified treatments was comparable between the 2

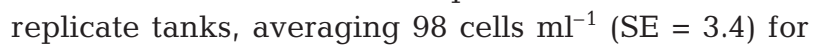
Tank 1 and 102 cells $\mathrm{ml}^{-1}(\mathrm{SE}=3.7)$ for Tank 2 . The control tanks contained an approximately equivalent biovolume concentration of nontoxic Thalassiosira weissflogii cells averaging 1807 cells ml $^{-1}(\mathrm{SE}=85.7)$

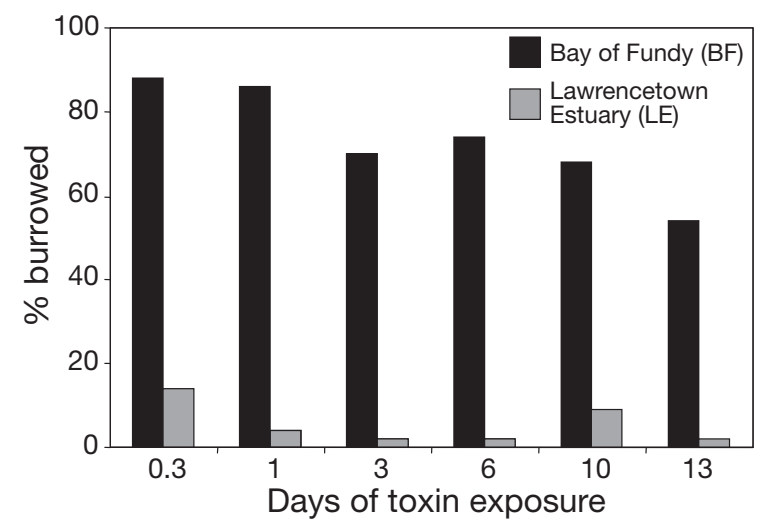

Fig. 1. Mya arenaria. Repeated burrowing response (percent of clams of each source population which burrowed after $2 \mathrm{~h}$ following exposure at the sediment surface) of clams exposed to the toxigenic dinoflagellate Alexandrium tamarense (strain PR18b) in Expt I valves. After $7 \mathrm{~h}$ of exposure the ability of most individuals from the LE population to re-burrow in the sediment was significantly reduced by the presence of toxic Alexandrium cells, compared to clams from BF ( $<<0.001, F=96.4, \mathrm{df}=1$ ) (Fig. 1). Incapacitated LE clams remained in a horizontal position on the sediment surface with the foot partially to fully extended (no probing of substrate) and non-responsive to physical stimuli. Less than $10 \%$ of the population was able to burrow throughout the experimental period. Percent burrowing of $\mathrm{BF}$ clams was $88 \%$ after $7 \mathrm{~h}$ of toxin exposure, but was significantly reduced over time ( $\mathrm{p}=$ $0.005, F=30.7$ ) to a low of $54 \%$ after $13 \mathrm{~d}$ of exposure. A small proportion of individual LE clams (2 to 14\%) were able to burrow throughout the experiment despite the presence of toxins. Conversely, a percentage of BF clams (12 to $46 \%$ ) were unable to burrow during toxin exposure, thus indicating the presence of 2 distinct phenotypes within each of the 2 populations. There was no significant difference in time required to burrow between BF clams (mean $=44.5 \mathrm{~min}$, range $=$ 14.7 to $114.0 \mathrm{~min}, \mathrm{~N}=49$ ) and LE clams (mean = $50.1 \mathrm{~min}$, range $=26.1$ to $98.5 \mathrm{~min}, \mathrm{~N}=12)(\mathrm{p}=0.430$, $F=0.63, \mathrm{df}=1)$.

\section{Feeding rates}

Observations conducted during feeding trials showed flared, distended siphons with extended guard tentacles in BF clams, whereas most LE clams exhibited a reduced siphon diameter or crimped siphons (both inhalant and exhalent). CR of BF clams was significantly higher than that of LE clams for all 3 exposure times, Day 1 ( $p<0.001)$, Day 7 ( $<<0.001)$ and Day 14 ( $p<0.001$ ) (Fig. 2). Feeding rates of LE clams did not change significantly during the $14 \mathrm{~d}$ of expo-

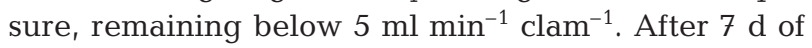
exposure feeding rates for $\mathrm{BF}$ clams were significantly 


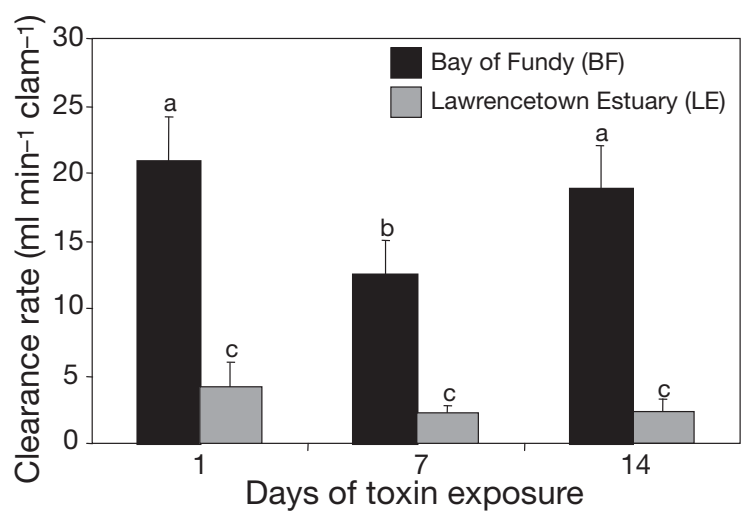

Fig. 2. Mya arenaria. Repeated clearance rate (mean $\pm \mathrm{SE}$ ) of clams from 2 source populations exposed to Alexandrium tamarense (strain PR18b) in Expt I. Different letters indicate statistically significant differences as determined by 2 -way ANOVA $(\alpha=0.05)$. Tissue wet weight (mean $\pm \mathrm{SE}$ ): $\mathrm{LE}=1.87 \mathrm{~g} \pm 0.06 ; \mathrm{BF}=2.14 \mathrm{~g} \pm 0.10$

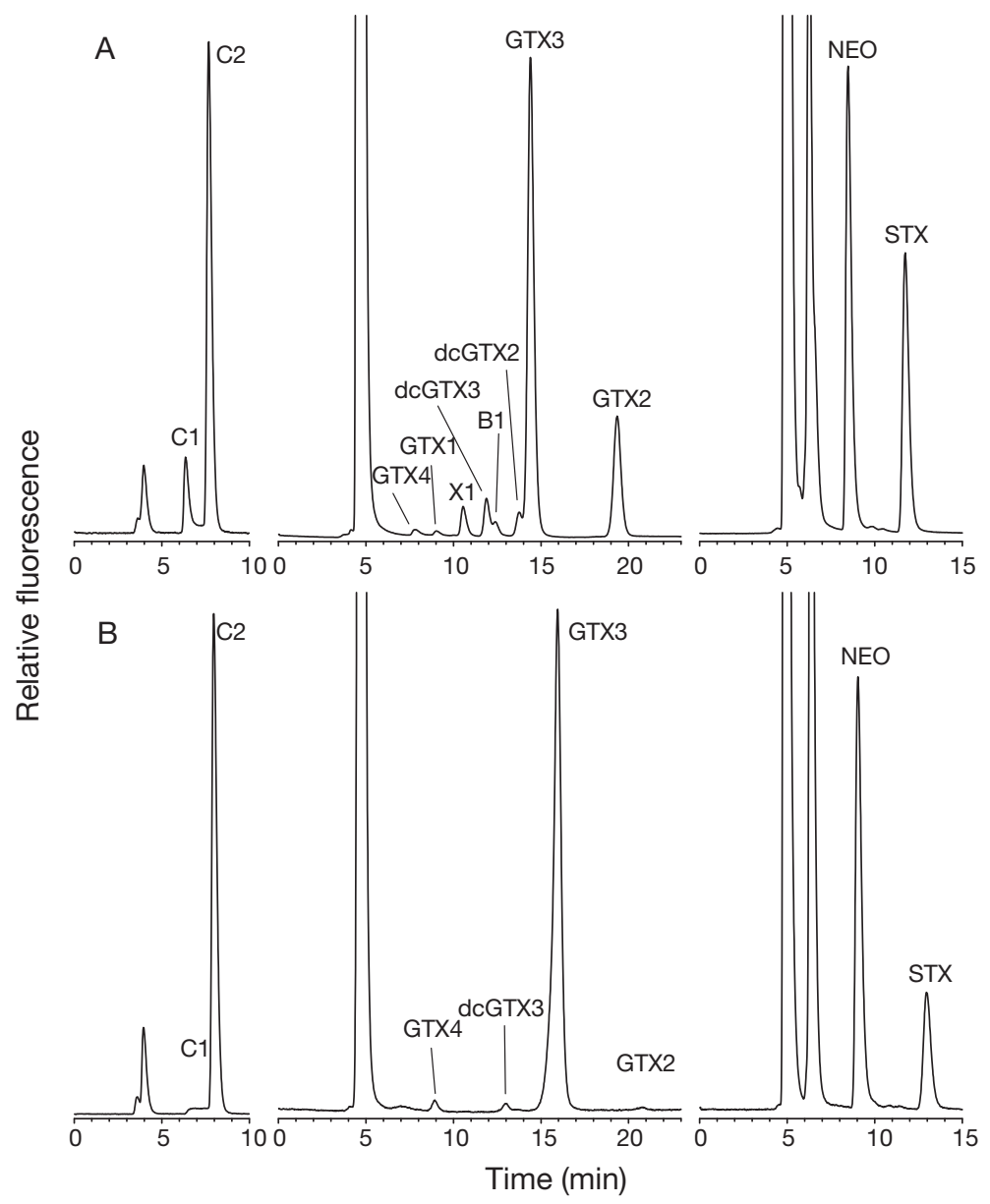

Fig. 3. Mya arenaria. Representative chromatograms from high-performance liquid chromatography (HPLC) toxin analysis. (A) M. arenaria visceral extract; (B) Alexandrium tamarense (PR18b) extract. Note the unknown toxin (X1) present in the clam tissues but not in the phytoplankton extract (identified by Quilliam et al. [2001] from samples provided from the present study) lower $\left(\right.$ mean $\left.=12.5 \mathrm{ml} \mathrm{min}{ }^{-1} \mathrm{Clam}^{-1}\right)$ than those measured at $24 \mathrm{~h}$ and $14 \mathrm{~d}$ of exposure (means of 18.1 and $18.8 \mathrm{ml} \mathrm{min}^{-1} \mathrm{Clam}^{-1}$, respectively) ( $\mathrm{p}=0.045, F=4.2$, $\mathrm{df}=2)$.

\section{Toxin accumulation}

Toxin analysis revealed a previously unknown PST derivative in clam tissue extracts that was absent in the Alexandrium tamarense cell extracts. This toxin was not included in calculations of total toxicity as its relative potency remains unknown. Fig. 3 shows representative chromatograms of clam visceral extract compared to that of isolate PR18b.

Mya arenaria from the BF population accumulated significantly higher total body toxin levels over the exposure period compared to the LE population ( $\mathrm{p}<$ 0.001, 2-way ANOVA, Fig. 4A). Removal of rare phenotypes from each population (based on individual burrowing response at $24 \mathrm{~h}$ exposure) resulted in a maximum 9-fold difference in mean toxicity at $7 \mathrm{~d}$ of exposure between the 2 populations (Fig. 4B). Although based on a few individuals on each sampling date, the toxicity of rare phenotypes within each test population was typically markedly different from that of common phenotypes, with burrowers (resistant clams) having a higher toxicity than non-burrowers (sensitive clams), supporting the theory that 2 distinct phenotypes exist within each population.

Clams from both populations exceeded the regulatory limit of $80 \mu \mathrm{g}$ STXeq $100 \mathrm{~g}^{-1}$ after $24 \mathrm{~h}$ of toxin exposure, on average by 27-fold for BF clams and 15-fold for LE clams. Assuming a linear toxin accumulation rate over the first $24 \mathrm{~h}, \mathrm{BF}$ and LE clams would have reached the regulatory limit in $<1 \mathrm{~h}$ and $<2 \mathrm{~h}$, respectively. Toxicities of LE clams did not increase substantially after $24 \mathrm{~h}$ of toxin exposure, reaching only 1.5 times this level by the end of the experiment. Toxin levels in the viscera of the 2 populations (calculated only for the common or dominant phenotype) differed significantly (data not shown). Toxicity of BF clams peaked at $77000 \mu \mathrm{g}$ STXeq $100 \mathrm{~g}^{-1}\left(4037 \mathrm{nmol} \mathrm{g}^{-1}\right)$ after $15 \mathrm{~d}$, whereas LE clams attained an order of magnitude lower toxicity at $8200 \mu \mathrm{g}$ STXeq $100 \mathrm{~g}^{-1}$ $\left(431 \mathrm{nmol} \mathrm{g}^{-1}\right)$. Peak toxicity in the other tissues among the common phenotypes 


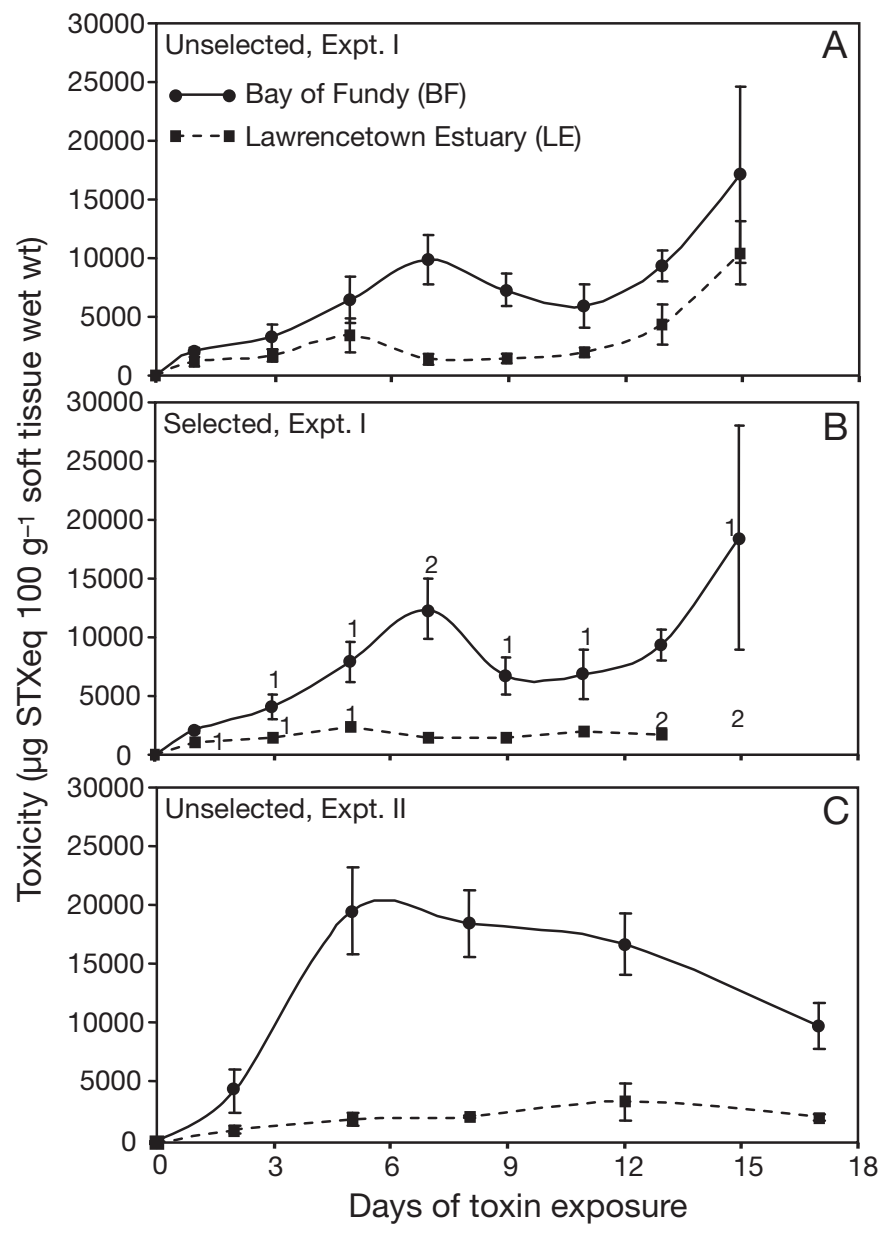

Fig. 4. Mya arenaria. Total body toxicity ( $\mu$ g STXeq $100 \mathrm{~g}^{-1}$ ) of clams from 2 populations exposed to Alexandrium tamarense (mean \pm SE, $\mathrm{n}=5$ clams). (A) Expt I, all data included; (B) Expt I, only dominant phenotypes included, i.e. resistant BF clams and sensitive LE clams as determined from the burrowing response at $24 \mathrm{~h}$. Numbers in bold indicate no. of clams with rare phenotypes removed; (C) Expt II, all data included. Curves drawn by smoothed line interpolation between data points

(data not shown) was twice as high in the BF population $\left(1600 \mu \mathrm{g}\right.$ STXeq $\left.100 \mathrm{~g}^{-1}, 78 \mathrm{nmol} \mathrm{g}^{-1}\right)$ as in the LE population $\left(800 \mu \mathrm{g}\right.$ STXeq $\left.100 \mathrm{~g}^{-1}, 17 \mathrm{nmol} \mathrm{g}{ }^{-1}\right)$. Total body toxicity was 3 times higher in the BF clams used to determine feeding rates $\left(9723 \mu \mathrm{g}\right.$ STXeq $100 \mathrm{~g}^{-1}, \mathrm{SE}=$ 1270) than in the LE clams (2916 $\mu \mathrm{g}$ STXeq $100 \mathrm{~g}^{-1}, \mathrm{SE}=$ $645)$ after $14 \mathrm{~d}$ of exposure $(\mathrm{p}=0.002)$.

In Expt II, total body toxicity in BF clams reached a maximum of $\sim 20000 \mu \mathrm{g}$ STXeq $100 \mathrm{~g}^{-1}$ (1053 $\mathrm{nmol} \mathrm{g}{ }^{-1}$ ) after only $5 \mathrm{~d}$ of exposure (Fig. 4C), a level reached in Expt I only after $15 \mathrm{~d}$ of exposure. However, marked differences in toxicities attained by the 2 test populations were again evident. LE clams accumulated significantly less toxin $(p<0.001)$ reaching a maximum of only $3300 \mu \mathrm{g}$ STXeq $100 \mathrm{~g}^{-1}\left(174 \mathrm{nmol} \mathrm{g}^{-1}\right)$ after $12 \mathrm{~d}$ of exposure, a value representing only $16 \%$ of the maximum of the BF population. Toxicity in BF clams exhibited a significant downward trend after reaching the maximum, attaining $50 \%$ of peak toxicity at the end of $17 \mathrm{~d}$, whereas no significant decline in toxicity was evident in the LE population. As in Expt I, the toxicity pattern of BF clams did not allow description of toxin kinetics by fitting simple, standard equations. Toxin accumulation in the viscera contributed ca. $80 \%$ of the total body toxin burden and exhibited similar patterns as total body toxin accumulation. BF clams reached $68000 \mu \mathrm{g}$ STXeq $100 \mathrm{~g}^{-1}$ in the viscera at $8 \mathrm{~d}$, whereas LE clams accumulated significantly less toxin (12 $000 \mu \mathrm{g}$ STXeq $100 \mathrm{~g}^{-1}, \mathrm{p}<0.001$ ) in the viscera after $12 \mathrm{~d}$ of exposure. Relative toxicity patterns in other tissues were similar to those described for the viscera with peak toxicities of $3200 \mu \mathrm{g}$ STXeq $100 \mathrm{~g}^{-1}$ in BF clams and only $750 \mu \mathrm{g}$ STXeq $100 \mathrm{~g}^{-1}$ in LE clams after $12 \mathrm{~d}$. These differences were highly significant $(\mathrm{p}<$ 0.001). The 2 populations did not differ in gross anatomical compartmentalization of toxins. Consistent results were obtained in both experiments, indicating that although viscera only made up 15 to $20 \%$ of total tissue weight, this tissue contributed 80 to $85 \%$ of total toxins in both clam populations.

Percent molar toxin composition of the viscera of both populations did not differ significantly from that of Alexandrium tamarense cells (BF: $\mathrm{p}=0.372$, LE: $\mathrm{p}=$ 0.205) (Table 1). However, when comparing the toxin composition of the other tissues pool with A. tamarense cells, there was a significant increase in the more potent carbamate toxins $(\mathrm{NEO}+\mathrm{STX})(\mathrm{BF}: \mathrm{p}=0.003, \mathrm{LE}: \mathrm{p}<$ $0.001)$ as well as a significant reduction in the less potent $\mathrm{N}$-sulfocarbamoyl toxins $(\mathrm{C} 1+2)(\mathrm{p}<0.001)$ in both populations. A comparison of the 2 major toxin groups between the 2 clam populations showed that there was no significant difference in either the relative amount (\% molar) of N-sulfocarbamoyl (BF $=68.3 \%$, LE $=67.4 \%$, $\mathrm{p}=0.392, F=0.781)$ or carbamate toxins $(\mathrm{BF}=27.6 \%$, $\mathrm{LE}=28.6 \%, \mathrm{p}=0.368, F=0.865)$ in the viscera. The LE population did, however, have a significantly higher relative content of carbamate toxins $(\mathrm{BF}=31.7 \%, \mathrm{LE}=$ $38.1 \%, \mathrm{p}=0.014, F=7.929$ ) and a significantly lower one of $\mathrm{N}$-sulfocarbamoyl toxins $(\mathrm{BF}=62.9 \%$, LE $=$ $56.5 \%, p=0.006, F=10.648)$ in the other tissues compared to the BF population. This pattern of carbamate enrichment in the other tissues was also evident in the LE population in Expt II (data not shown).

\section{Oxygen consumption rates}

$\mathrm{VO}_{2}$ rates for Mya arenaria fed Alexandrium tamarense were significantly reduced, by $80 \%$, in LE clams at $2 \mathrm{~d}(\mathrm{p}=0.002)$ and by $60 \%$ at $18 \mathrm{~d}(\mathrm{p}=0.038)$ 


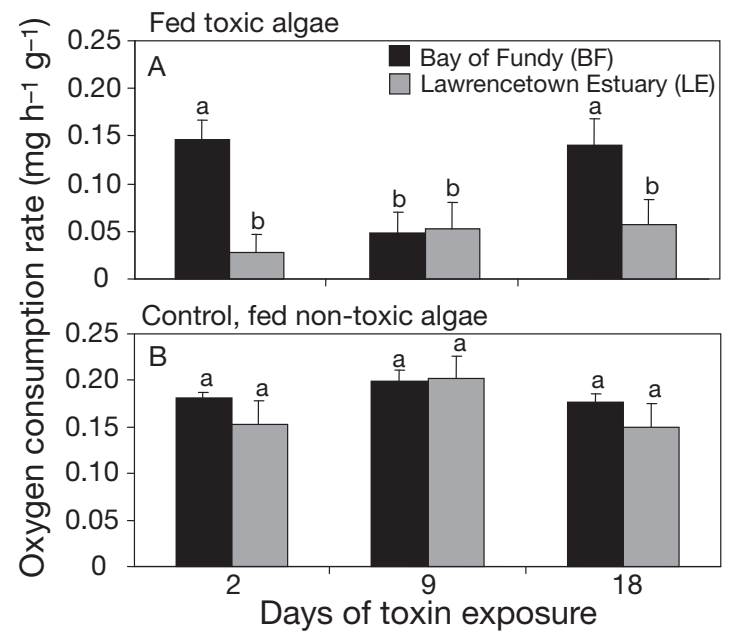

Fig. 5. Mya arenaria. Weight-specific oxygen consumption rates (mean $\pm \mathrm{SE}$, based on soft tissue wet weight) of clams from the 2 source populations over the $18 \mathrm{~d}$ of toxin exposure in Expt II. (A) Toxified treatment, (B) controls exposed to nontoxic algae (Thalassiosira weissflogii). Different letters indicate statistically significant differences as determined by 2-way ANOVA $(\alpha=0.05)$

relative to those of $\mathrm{BF}$ clams. However, $\mathrm{VO}_{2}$ of clams from both populations was significantly reduced (and comparable) at $9 \mathrm{~d}$ of exposure relative to nontoxic controls $(\mathrm{p}<0.001)$ (Fig. 5A). This reduction in $\mathrm{VO}_{2}$ for the $\mathrm{BF}$ population at the midpoint of the toxin exposure period coincides with the reduction in feeding rates after $7 \mathrm{~d}$ in Expt I. However, there was no difference in $\mathrm{VO}_{2}$ between BF clams fed toxic $A$. tamarense on Days 2 and 18. These overall differences in $\mathrm{VO}_{2}$ between $M$. arenaria populations are consistent with the results of a preliminary $\mathrm{VO}_{2}$ trial conducted in Expt I, which showed a $40 \%$ reduction in the sensitive (LE) relative to the resistant (BF) population fed $A$. tamarense after $8 \mathrm{~d}$ of exposure (data not shown). Measurements of $\mathrm{VO}_{2}$ for clams from both populations fed the nontoxic Thalassiosira weissflogii control diet showed no significant difference between populations or over time (Fig. 5B).

\section{Mortality rates}

In Expt I LE clams exhibited marked cumulative mortalities which started after $7 \mathrm{~d}$ of toxin exposure and reached $42 \%$ among clams that remained undisturbed in the sediment and $26 \%$ for clams repeatedly removed from sediment after $16 \mathrm{~d}$ of exposure. In contrast, BF clams experienced $<2 \%$ mortality by the end of toxification (Fig. 6). Although cumulative mortality among LE clams that were left undisturbed was higher than that for clams that were regularly removed from the sediment during sampling (handled), differential mortality of LE relative to BF clams was evident in both groups. Clams from both populations from the same collection date as the experimental clams, held in parallel in the raceway system and fed nontoxic algae, suffered no mortality over the course of the experiment. The exact timing of mortality among sensitive clams was difficult to determine as live but incapacitated (paralyzed) clams are difficult to distinguish from recently dead clams. Only clams exhibiting obvious signs of morbidity (blackened mantle and siphon, strong odor, decomposing soft tissues) were removed and included in mortality counts. Thus PSTs were lethal to sensitive clams and differentially affected survival in the 2 test populations.

In Expt II, the dominantly sensitive population (LE) suffered significantly higher mortalities than the dominantly resistant population $(\mathrm{BF})(\mathrm{p}<0.001)$ (Fig. 7): mortalities of LE clams began within ca. $1 \mathrm{wk}$ as in Expt I, and reached $16 \%$ at $23 \mathrm{~d}$ of toxin exposure, whereas they began at $10 \mathrm{~d}$ of exposure and reached $8 \%$ in BF clams. During the same exposure period, no mortality occurred in the 2 nontoxic, control tanks for either population. Phenotype-specific mortalities were calculated, although this experiment was not designed for this purpose; their determination is the subject of a follow-up study using larger sample sizes of rare phenotypes within each population. Based on burrowing response at $24 \mathrm{~h}$ of toxin exposure, sensitive individuals (non-burrowers) showed higher mortalities compared to resistant individuals (burrowers) within the same population (Fig. 7 inset). However, caution should be exercised in interpreting these preliminary results due to the small sample sizes $(\mathrm{n}=$ 6 to 14 ) of the rare phenotypes within each population.

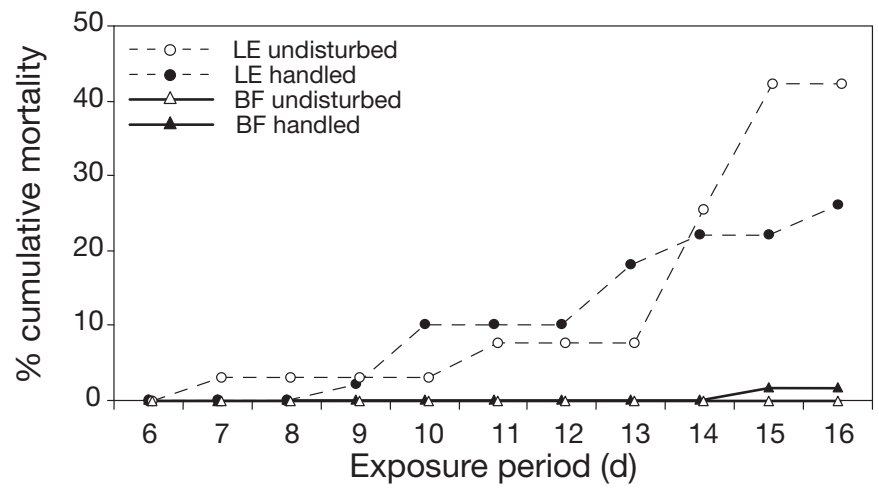

Fig. 6. Mya arenaria. Cumulative mortality of clams from 2 source populations (Expt I) exposed to Alexandrium tamarense (strain PR18b). Solid line = Bay of Fundy $(\mathrm{BF})$; broken line = Lawrencetown Estuary $(\mathrm{LE})$; solid symbols = handled $($ Tank 1$) ;$ open symbols = undisturbed clams $($ Tank 2 ; see text) 


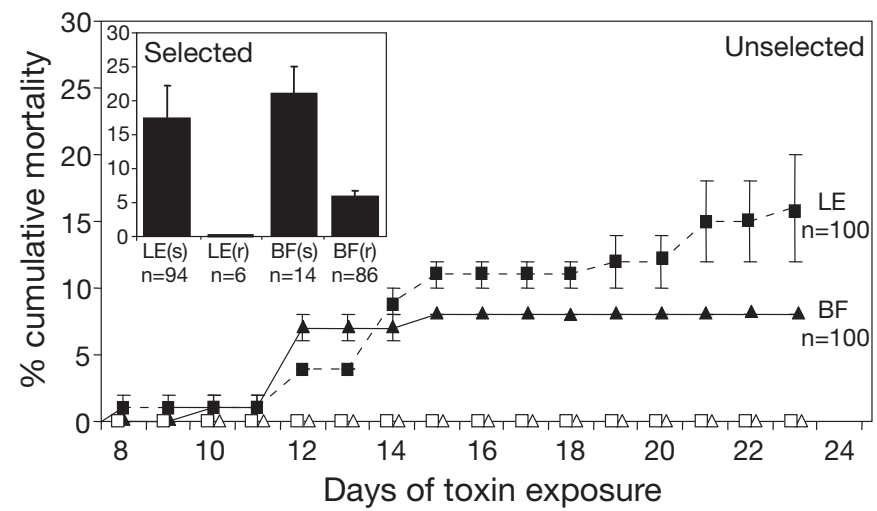

Fig. 7. Mya arenaria. Cumulative mortality (mean of 2 tanks \pm $\mathrm{SE})$ for the 2 test populations exposed to Alexandrium tamarense (strain PR18b) (Expt II). Toxified clams including both resistant and sensitive phenotypes as determined by burrowing at $24 \mathrm{~h}$ (solid symbols), and non-toxic controls (open symbols); solid line = Bay of Fundy $(\mathrm{BF})$; broken line $=$ Lawrencetown Estuary (LE). Inset compares cumulative mortalities of clam phenotypes at the end of the experiment (Day 23); $\mathrm{s}=$ sensitive, $\mathrm{r}=$ resistant

\section{DISCUSSION}

Overall, this study demonstrates that there are marked differences in burrowing behavior, feeding, metabolic rates, toxin accumulation and survival between sensitive and resistant populations of Mya arenaria and that these differences are maintained over $2 \mathrm{wk}$ of exposure to toxic dinoflagellate cells. These findings support and expand on previous research which showed that $\mathrm{LE}$ and BF populations differ greatly in prevalence of resistant and sensitive clams, as determined by the in vitro nerve effects of STX, and in their genotype composition determined from the Domain II $\mathrm{Na}^{+}$channel gene sequence (Bricelj et al. 2005, Connell et al. 2007). The combined results of these studies strongly support Twarog's (1974) hypothesis that exposure to PSTs can result in selection for toxin resistance in natural shellfish populations.

\section{Behavioral responses}

Mya arenaria populations with contrasting histories of PST exposure exhibited marked variation in their behavioral responses (burrowing and siphon retraction) during laboratory exposure to toxins. Paralytic shellfish toxins block $\mathrm{Na}^{+}$channels in nerves, thus preventing the conductance of an action potential along nerve fibers (Narahashi et al. 1967). Burrowing in $M$. arenaria is a complex, hydraulic process, involving several muscular systems that work simultaneously (Trueman 1966, Checa \& Cadée 1997). Each of these is under nervous control and thus can be affected by
PSTs. The foot is innervated by the pedal nerve under the control of the pedal ganglia, whereas siphon retraction is controlled by the visceral ganglia via the pallial nerve (Stefano et al. 1990). It is difficult to discern which of these neuromuscular systems is most affected by PSTs, but visual observations of foot extension, valve gape and lack of siphon retraction among sensitive individuals suggest that burrowing inhibition is the result of loss of nervous control of all or a combination of these systems.

The percentage of sensitive (non-burrowers) to resistant (burrowers) individuals varied among the 2 Mya arenaria populations in relation to their previous PSP histories: the LE population (no history of toxin exposure) was predominantly comprised of sensitive individuals, whereas the BF population (annual, recurrent PSP outbreaks) was dominated by resistant individuals. The percent of resistant clams (4 to $8 \%$ ) in the LE population was consistent between Expts I and II. Bricelj et al. (1996) found similar effects on burrowing when a $M$. arenaria population from Long Island, New York, (no history of PSP) was exposed to a toxic Alexandrium tamarense (strain PR18b): only 7 to $31 \%$ of clams were able to burrow in the presence of toxins over the $11 \mathrm{~d}$ exposure period.

Impaired burrowing and siphon retraction in infaunal bivalves can have important ecological consequences in the natural environment. In addition to the toxin-induced mortalities demonstrated in the laboratory, clams that are sensitive to PSTs are likely to be exposed to increased predation and desiccation in the intertidal during toxin events. Impaired clams are likely to be exposed at the sediment surface due to tidally induced scour in a high-energy environment such as the BF and are thus expected to be more vulnerable to predation. Increased risk of predation by demersal fish and crabs during high tide and predation by birds, gulls in particular, during low tides was suggested by Emerson et al. (1990) when sublegal-sized clams were discarded during intertidal harvesting. The lack of siphon response could lead to increased vulnerability to siphon-cropping fish, known to adversely affect growth of infaunal bivalves (Peterson \& Skilleter 1994). Fitness differences between sensitive and resistant phenotypes due to direct or indirect effects of PSTs during red tides could thus lead to selection of the more resistant clams during toxin exposure in nature.

\section{Feeding and $\mathrm{VO}_{2}$ rates}

Previous studies have shown interspecific differences in the feeding response of bivalves to PSTproducing dinoflagellates. Mytilus edulis, a species with nerves resistant to STX, feeds readily on toxic 
Alexandrium cells (Bricelj et al. 1990), whereas oysters Crassostrea virginica (Shumway \& Cucci, 1987) and C. gigas (Bardouil et al. 1993, 1996) exhibit severe feeding inhibition. In the present study, we first demonstrate significant differences in feeding rate on toxic cells among bivalve populations of the same species related to their prior history of toxin exposure and genotypic composition (as reported in Bricelj et al. 2005). Thus, exposure to a unialgal suspension of highly toxic $A$. tamarense cells caused severe feeding inhibition (up to $80 \%$ ) among Mya arenaria from a population with no prior exposure to PSP, whereas clams from a historically exposed population maintained CRs on toxic cells significantly higher than those of sensitive clams. The mean CR of clams from the 2 populations also correlated with their nerve sensitivity to PSTs (Bricelj et al. 2005) and their differential toxin accumulation capacity, as demonstrated in the present study.

Weight-specific CRs of resistant clams (mean $=50 \mathrm{ml}$ $\min ^{-1} \mathrm{~g}^{-1}$ dry wt) were comparable to those obtained for similar-sized Mya arenaria fed nontoxic diets under

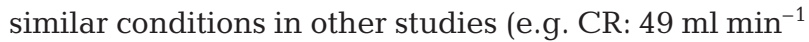
$\mathrm{g}^{-1}$ dry wt in Riisgård \& Seerup [2003]). Bivalves can reduce the ingestion of undesirable or toxic particles via reduction of pumping rate and/or selective rejection in pseudofeces. Shumway \& Cucci (1987) exposed $M$. arenaria from a population in Maine, USA, to a nontoxic suspension spiked with toxic Alexandrium tamarense cells (strain GT429, at 500 cells ml$^{-1}$, cell toxicity not quantified). Clams removed toxic cells from this suspension at a rate $28 \%$ below that of the nontoxic control, but rejected cells via copious pseudofeces production. In the present study, at a bloom density of $100 \mathrm{~A}$. tamarense cells $\mathrm{ml}^{-1}$, no production of pseudofeces was observed. Thus, the observed differences in feeding rates between sensitive and resistant clams can be attributed to differences in CR (or pumping rate, as $A$. tamarense exceeds the size threshold for $100 \%$ retention efficiency by the gill [Møhlenberg \& Riisgård 1978]). Bricelj et al. (1996) compared CR of $M$. arenaria (from the LE population) fed 3 strains of $A$. tamarense ranging from nontoxic to highly toxic and a nontoxic control of Thalassiosira weissflogii. They found no reduction in CR in clams offered the moderate $\left(20 \mathrm{pg}\right.$ STXeq $\left.\mathrm{cell}^{-1}\right)$ or nontoxic strain of $A$. tamarense compared to the control following shortterm (2 to $3 \mathrm{~h}$ ) exposure, but $\mathrm{CR}$ on the highly toxic PR18b strain was significantly reduced (by $90 \%$ ). CR for clams offered the highly toxic strain in a mixture with nontoxic $T$. weissflogii (30\% toxic A. tamarense cells based on volume) did not differ significantly from that of the control. The present study used unialgal suspensions of toxic Alexandrium to simulate red tides, which are largely monospecific at the peak of the bloom. Future studies should determine whether feeding rate differences between resistant and sensitive clams are also observed in mixed assemblages of toxic and nontoxic phytoplankton, as often observed during bloom initiation and termination phases.

The high individual and temporal variability in CR shown in the present study within a given Mya arenaria population suggests that $\mathrm{CR}$ inhibition is less useful than burrowing incapacitation for characterization of individual toxin sensitivity in this species. Feeding rate measurements, however, may be very useful to determine toxin sensitivity of epifaunal, nonburrowing species.

In bivalves, food particles are drawn into the mantle cavity by gill ciliary feeding currents, captured on the gill and transported to the mouth in ciliated food tracts. The amount of current generated by the gills is a function of the ciliary beat frequency (CBF) of the lateral cilia which can be altered as a means of varying the amount of particles brought in contact with the gills. Although ciliary beating is autonomous, CBF is under nervous control by the visceral ganglion via the branchial nerve (Aiello \& Guideri 1965). Aiello (1960) discovered that by cutting the branchial nerve in Mytilus edulis the cilia continued to beat, but at a highly reduced rate which could persist for several days. Video-endoscopy observations of Mya arenaria during feeding on Alexandrium tamarense (strain PR18b) showed muscular convulsions, contraction and collapse of the gill, typically within 10 min of exposure to toxic cells (Bricelj et al. 1998). In an individual clam exhibiting no response to tactile stimuli (after $10 \mathrm{~h}$ of exposure), the gill appeared fully relaxed and no intrapallial feeding currents were detected. Thus, the loss of nervous system control of the gill caused by toxininduced block of the $\mathrm{Na}^{+}$channel in sensitive individuals could explain the feeding inhibition observed among sensitive clams. The mechanism involved appears to be post-ingestion incapacitation rather than chemosensory detection of PSTs. This hypothesis is supported by our visual observations indicating that sensitive clams can feed readily upon initial exposure to toxic cells, but subsequently experience feeding inhibition, including loss of ability to extend, contract or dilate the siphon for feeding.

Mya arenaria from the sensitive LE population also showed significant reduction (60 to $80 \%$ ) in $\mathrm{VO}_{2}$ in the presence of toxic Alexandrium tamarense compared to clams from the resistant $\mathrm{BF}$ population and to those fed a nontoxic, control alga. $\mathrm{VO}_{2}$ of $\mathrm{BF}$ clams did not differ significantly from that of the control group with the exception of measurements conducted midway through the experiment ( $9 \mathrm{~d}$ exposure), when $\mathrm{VO}_{2}$ was significantly reduced $(75 \%)$ in both test populations. A reduction in $\mathrm{CR}$ was also observed for BF clams in 
Expt I after a similar exposure period ( 7 to $9 \mathrm{~d}$ ), suggesting that even resistant clams are eventually affected by sufficiently high PST levels in the tissues. Physiological functions such as feeding and metabolic rate may thus be negatively affected once a threshold toxicity level is reached. In contrast to these results, Shumway et al. (1985) found that $5 \mathrm{~d}$ of exposure of $M$. arenaria to toxic Alexandrium cells caused an increase in $\mathrm{VO}_{2}$ with a subsequent decrease to normal values after $1 \mathrm{wk}$ of recovery. The collection site was not specified, so clams are of unknown PST sensitivity. However, their results for the sea scallop Placopecten magellanicus and surf clams Spisula solidissima are consistent with results from the present study that show a reduction in $\mathrm{VO}_{2}$ during toxin exposure. Gainey \& Shumway (1988) showed no significant effect of toxic cells on cardiac activity in $M$. arenaria collected from Long Cove, Searsport, Maine, USA.

The reduction in mantle cavity irrigation rate caused by PST-induced loss of nervous control of the gill could result in an oxygen deficit and an increase in anaerobic metabolism. Mya arenaria experience daily aerial exposure in the intertidal. However, extended toxininduced paralysis (on the order of days to weeks) could result in reduced intrapallial flushing and lead to hypoxic or anoxic conditions and accumulation of anaerobic end products. Future studies should investigate the contribution of anaerobic metabolism to total metabolic rate in relation to toxin resistance.

It is difficult to predict the overall impacts of differential toxin sensitivity on scope for growth of Mya arenaria populations, as other parameters such as absorption efficiency of Alexandrium cells and total metabolic rate (including anaerobic metabolism) would need to be determined. Scope for growth of sensitive individuals may not necessarily be reduced relative to resistant clams given that, in the former, both $\mathrm{VO}_{2}$ and ingestion rate decrease during toxin exposure.

\section{Toxin accumulation}

High variability in toxin accumulation in individuals within a bivalve species in relation to environmental parameters such as position in the intertidal zone and microhabitat differences has been described previously (Quayle 1969, Shumway et al. 1994, Curtis et al. 2000). However, this study in conjunction with that of Bricelj et al. (2005) presents the first detailed investigation of intraspecific behavioral and physiological differences associated with history of toxin exposure and its relationship with genotypic differences. Toxin uptake in tissues is expected to be correlated with ingestion rates of toxic cells in suspension-feeding bivalves, and this is demonstrated for Mya arenaria in the present study. Most of the toxin is generally retained in the visceral mass $(\sim 80 \%)$ during toxification (Bricelj \& Shumway 1998), as confirmed in the present study for $M$. arenaria from both sensitive and resistant populations. Sensitive clams readily fed upon toxic cells during initial exposure, until a threshold level in total body toxicity (2000 to $3000 \mu \mathrm{g}$ STXeq $100 \mathrm{~g}^{-1}$ ) was reached, which in turn was followed by a reduction in feeding rates. This pattern of ingestion for sensitive clams is evident in the toxin accumulation patterns where a maximum toxin level is reached early during toxification and remains relatively unchanged with continued toxin exposure. Total toxin body burden in sensitive clams ranged from $1700 \mu \mathrm{g}$ STXeq $100 \mathrm{~g}^{-1}\left(89 \mathrm{nmol} \mathrm{g}^{-1}\right)$ in Expt I to $3300 \mu \mathrm{g}$ STXeq $100 \mathrm{~g}^{-1}$ $\left(174 \mathrm{nmol} \mathrm{g}^{-1}\right)$ tissue WW in Expt II. In contrast, resistant $M$. arenaria, which were relatively unaffected by toxins, continued to ingest toxin cells and incorporate toxins in their tissues, reaching an extremely high total toxin body burden $\left(18000\right.$ and $20000 \mu \mathrm{g}$ STXeq $100 \mathrm{~g}^{-1}$ [948 and $1053 \mathrm{nmol} \mathrm{g}^{-1}$ ] in Expts I and II, respectively) during extended periods ( $2 \mathrm{wk}$ ) of exposure.

The pattern and magnitude of toxin accumulation in Expt I was influenced by the differential survival rates of sensitive and resistant clams within the 2 test populations. Selective mortality of more sensitive LE clams resulted in an increased proportion of resistant clams with a higher toxin accumulation capacity by the end of the exposure period (Fig. 3A,B). Non-asymptotic toxin accumulation was observed in Expt II in which maximum total body toxicity (19500 $\mu$ g STXeq $100 \mathrm{~g}^{-1}$ ) was reached after $5 \mathrm{~d}$ of exposure, followed by a decrease in toxicity for the remainder of the $17 \mathrm{~d}$ experiment. Maximum toxicities attained by BF clams were comparable between the 2 experiments, ranging from 12500 to $19500 \mu \mathrm{g}$ STXeq $100 \mathrm{~g}^{-1}$. However, the toxicity maximum was reached earlier, after only $5 \mathrm{~d}$ of exposure in Expt II compared to $15 \mathrm{~d}$ in Expt I. This may be the result of the higher toxicity of Alexandrium tamarense, 98 pg STXeq cell ${ }^{-1}$ in this experiment, versus $61 \mathrm{pg}$ STXeq cell ${ }^{-1}$ in Expt I. Fluctuations in feeding and toxin uptake in BF clams further support the hypothesis of intermediate toxin resistance in Mya arenaria, compared to highly resistant species such as Mytilus edulis which experience a monotonic increase in toxicity over time until an asymptote is reached (Bricelj et al. 1990). Prediction of toxin uptake kinetics in $M$. arenaria is thus expected to be a function of the composition of resistant and sensitive individuals in a given population.

There are few studies of laboratory PSP toxification of Mya arenaria with which to compare results from the present study. Bricelj et al. (1996) exposed M. arenaria (from Long Island, New York, an area with no history of PSP) and Spisula solidissima to Alexandrium 
tamarense (strain PR18b, 74.5 pg STXeq cell ${ }^{-1}$ ) under comparable conditions. $M$. arenaria reached $1340 \mu \mathrm{g}$ STXeq $100 \mathrm{~g}^{-1}$, whereas $S$. solidissima reached a mean total body toxicity of $\sim 30000 \mu \mathrm{g}$ STXeq $100 \mathrm{~g}^{-1}$ after $11 \mathrm{~d}$ of toxin exposure. The toxicities for $M$. arenaria closely match those obtained for the LE sensitive population in the present study.

Toxicities for Mya arenaria, derived from the PSP monitoring program in Lepreau Basin, indicate that clams can reach field toxicities comparable to those obtained in the present laboratory study; a maximum total body toxicity of $9100 \mu \mathrm{g}$ STXeq $100 \mathrm{~g}^{-1}$ was recorded in 1976 (Martin \& Richard 1996). These authors reported that Mytilus edulis from a BF population could reach toxicities $>28000 \mu \mathrm{g}$ STXeq $100 \mathrm{~g}^{-1}$, whereas co-occurring $M$. arenaria only attained toxicities $30 \%$ of that value.

Findings of this study have important implications for management of shellfish PSTs and toxin monitoring of Mya arenaria in Atlantic North America. Regardless of site or individual toxin sensitivity, $M$. arenaria readily ingested toxic cells upon initial exposure to bloom conditions, exceeding the $80 \mu \mathrm{g}$ STXeq $100 \mathrm{~g}^{-1}$ regulatory limit within $4 \mathrm{~h}$ (all experiments) and in some cases within $1 \mathrm{~h}$ (assuming a linear toxin uptake during the first 24 to $48 \mathrm{~h}$ ). Individual variation could account for up to a 10-fold difference in total body toxicity among clams within a population and up to a 52-fold difference among individuals from different populations toxified under identical conditions. Monitoring of PSP in North America relies on pooling of several individuals (to attain $100 \mathrm{~g}$ total soft tissue WW) for determination of toxicity by the mouse bioassay and as a result will mask this inter-individual variation and could thus potentially underestimate public health risk.

Toxin composition in both the viscera and other tissues from both resistant and sensitive populations generally varied little from that of the toxin composition of ingested dinoflagellates. This agrees with prior studies which show that Mya arenaria has a limited capacity for biotransformation of PSTs (Martin et al. 1990, Laby 1997, Fast et al. 2006). Nevertheless, some significant changes in toxin composition were documented in $M$. arenaria in the present study. A shift from the less potent $\mathrm{N}$-sulfocarbamoyl toxins $(\mathrm{C} 1 \& 2)$ to the more potent carbamate toxins (NEO + STX) evident in the other tissues of the sensitive LE population is likely the result of non-enzymatic conversion. This is known to readily occur at low $\mathrm{pH}(\sim 3)$ (Hall et al. 1990) and could result from acidic conditions present in the gut. This observed compositional shift might be explained by selective retention of individual toxins. Sensitive individuals reduce their intake of toxic cells after a short exposure period, typically $<24 \mathrm{~h}$, presumably due to toxin incapacitation, while toxin transfer from the viscera to the other tissues continues despite the reduced influx of new toxins via ingestion. If carbamate toxins are selectively retained over $\mathrm{N}$-sulfocarbamoyl toxins or both groups of toxins have differential transfer efficiencies, the effects would be more pronounced in sensitive individuals as a result of the fixed toxin pool in the viscera available for transfer to other tissues. However, the small relative difference in toxin composition between LE and BF clams is insufficient to explain the marked differences in toxin uptake documented, as these are even more pronounced when expressed as molar concentrations.

\section{Toxin-induced mortality}

Two sequential experiments showed differential mortalities between the 2 clam populations in relation to their history of exposure to red tides in nature. Mortalities of sensitive LE clams typically started after $\sim 1 \mathrm{wk}$ of toxin exposure. Although both experiments yielded higher mortalities for sensitive than resistant clams, cumulative mortalities after 2 wk exposure were highly variable between experiments, ranging from 16 to $42 \%$. These differences cannot be explained by differences in algal cell toxicity, as this was higher in Expt II, or by the duration of toxin exposure, $23 \mathrm{~d}$ in Expt II compared to only $16 \mathrm{~d}$ in Expt I. Clam stocking density can also be ruled out as the cause of increased mortality, as this was higher in Expt II (625 clams $\mathrm{m}^{-2}$ ) than Expt I (312 clams $\left.\mathrm{m}^{-2}\right)$. An explanation for the variability in mortalities between experiments may be found in more subtle differences in experimental design, and in particular, the methods used to determine mortality rates. In Expt I, tanks were inspected daily for signs of moribund clams, but dead clams were not removed from the sediment. Clams showing signs of morbidity were often surrounded by a layer of black, anoxic sediment. In Expt II mortality estimates were based on removal of all clams from the sediment at $2 \mathrm{~d}$ intervals (and subsequent reintroduction of live clams to the sediment) to ensure that all clams were closely inspected and that the timing of mortality could be more accurately estimated. Periodic removal of the clams from the sediment in Expt II allowed flushing and reoxygenation of sediments, thus likely preventing the establishment of anoxic conditions. This was also the only experiment in which BF clams suffered detectable ( $8 \%$ ) mortality, and this may be associated with their proximity to the moribund LE clams within the tank. Both populations were kept mixed together in this experiment, whereas in Expt I populations were segregated at either ends of the tank. 
Several potential causes of mortality of sensitive Mya arenaria exposed to PSTs can be excluded. Starvation resulting from suppressed feeding in toxified, sensitive clams cannot be attributed a role in clam mortalities. MacQuarrie (2002) showed that when LE and BF clams at the sizes used in the present study were starved in the absence of sediment for $3 \mathrm{wk}$, negligible mortalities occurred. Landsberg (1996) suggested a link between PST exposure and the incidence of neoplasia in bivalves, including $M$. arenaria. However, Morrison et al. (1993) showed low levels of neoplasia occurrence in $M$. arenaria from 5 of 22 sites surveyed in the BF. Furthermore, histological analysis of both control and toxified clams (BF and LE) in Expt II showed no increase in the prevalence of neoplasia among the toxified group, discounting it as a possible cause for the increased mortality rates (V. M. Bricelj et al. unpubl. data). Neoplasia (based on analysis of $n=20$ clams per population), was detected in $\leq 10 \%$ of experimental clams and was thus typical of background levels for these populations.

Infaunal organisms, such as the lugworm Arenicola marina are known to enhance oxygen availability in the sediments through bioturbation and sediment reworking (Andersen \& Kristensen 1991, Retraubun et al. 1996). Infaunal suspension-feeding bivalves also have the ability, although to a lesser degree, to rework sediments during burrowing (Checa \& Cadée 1997) and oxygenate the surrounding sediments via circulation of water through the mantle cavity (Hansen et al. 1996). Sensitive clams are incapacitated by exposure to PSTs and are thus limited in their ability to generate feeding currents and reject or flush material from the pallial cavity, activities which allow replenishment of the food and oxygen supply in the body cavity and cleansing of incoming sediment. The observed reduction in $\mathrm{VO}_{2}$ may not be a result of a decrease in $\mathrm{O}_{2}$ demand but rather of a decrease in the exchange of gases at the gill and mantle surfaces due to reduced ventilation rates. This may lead to hypoxic and eventually anoxic conditions in the mantle cavity and the surrounding sediments and may be aggravated by bacterial decomposition of dead clams. This is supported by qualitative observations made during dissections, in which pockets of anoxic sediment were found within the mantle cavity of sensitive clams. Mya arenaria inhabits the intertidal zone and therefore experiences daily periods of anaerobiosis during low tides and has thus evolved mechanisms to tolerate periods of low oxygen levels. However, muscular paralysis and prolonged exposure to anaerobic conditions ( $>1 \mathrm{wk}$ ) may indirectly cause the observed mortality rates during prolonged toxin exposure. Our observations to date suggest that mortalities during exposure to toxic Alexandrium cells are not a direct effect of PSTs, but rather an indirect effect of toxin-induced paralysis and reduced irrigation of the mantle cavity. The association between anoxia/hypoxia within the pallial cavity and surrounding sediments and toxin-induced mortalities will be tested in future studies.

Acknowledgements. We thank at IMB/NRC: A. Bauder and S. McKenna for assistance with field collections and algal production, T. Windust for HPLC toxin analysis and G. Morstatt for construction of feeding chambers. This work was supported by a NOAA-ECOHAB Grant to V. L. Trainer (Northwest Fisheries Science Center) and V.M.B. and is part of an MS thesis by S.P.M. at Dalhousie University. This manuscript is ECOHAB publication \#261 and NRC-IMB publication \#2007-42755.

\section{LITERATURE CITED}

Aiello E (1960) Factors affecting ciliary activity on the gill of the mussel Mytilus edulis. Physiol Zool 33:120-135

Aiello E, Guideri G (1965) Distribution and function of the branchial nerve in the mussels. Biol Bull 129:431-438

Andersen FO, Kristensen E (1991) Effects of burrowing macrofauna on organic matter decomposition in coastal marine sediments. Symp Zool Soc Lond 63:69-84

Anderson DM, Keafer BA, McGillicuddy JDJ, Mickelson MJ and others (2005) Initial observations of the 2005 Alexandrium fundyense bloom in southern New England: general patterns and mechanisms. Deep-Sea Res II 52: 2856-2876

Bardouil M, Bohec M, Cormerais M, Bougrier S, Lassus P (1993) Experimental study of the effects of a toxic microalgal diet on feeding of the oyster Crassostrea gigas Thunberg. J Shellfish Res 12:417-422

Bardouil M, Bohec M, Bougrier S, Lassus P, Truquet P (1996) Feeding responses of Crassostrea gigas (Thunberg) to inclusion of different proportions of toxic dinoflagellates in their diet. Oceanol Acta Paris 19:177-182

Bauder AG, Bricelj VM, Craigie JS (2001) Semi-continuous culture of toxic Alexandrium tamarense in large-scale photobioreactors. In: Whyte JNC (ed) 7th Can Workshop Harmful Mar Algae. Can Tech Rep Fish Aquat Sci No. 2386, p 90-97

Bricelj VM, Shumway SE (1998) Paralytic shellfish toxins in bivalve molluscs: occurrence, transfer kinetics, and biotransformation. Rev Fish Sci 6:315-383

> Bricelj VM, Lee JH, Cembella AD, Anderson DM (1990) Uptake kinetics of paralytic shellfish toxins from the dinoflagellate Alexandrium fundyense in the mussel Mytilus edulis. Mar Ecol Prog Ser 63:177-188

Bricelj VM, Cembella AD, Laby D, Shumway SE, Cucci TL (1996) Comparative physiological and behavioral responses to PSP toxins in two bivalve molluscs, the softshell clam, Mya arenaria, and surfclam, Spisula solidissima. In: Yasumoto T, Oshima Y, Fukuyo Y (eds) Harmful and toxic algal blooms. Proc 7th Int Conf Toxic Phytoplankton, Sendai, p 405-408

Bricelj VM, Ward JE, Cembella AD, MacDonald BA (1998) Application of video-endoscopy to the study of feeding of bivalves on toxic and non-toxic dinoflagellates. J Shellfish Res 17:319-320

Bricelj VM, MacQuarrie SP, Twarog BM, Trainer VL (2004) Characterization of sensitivity to PSP toxins in North American populations of the softshell clam Mya arenaria. 
In: Steidinger KA, Landsberg JH, Tomas CR, Vargo GA (eds) Xth Int Conf Harmful Algae, St. Pete Beach, p 172-174

Bricelj VM, Connell L, Konoki K, MacQuarrie SP, Scheuer T, Catterall WA, Trainer VL (2005) Sodium channel mutation leading to saxitoxin resistance in clams increases risk of PSP. Nature 434:763-767

Cembella AD, Shumway SE, Lewis NI (1993) Anatomical distribution and spatio-temporal variation in paralytic shellfish toxin composition in two bivalve species from the Gulf of Maine. J Shellfish Res 12:389-403

- Checa AG, Cadée GC (1997) Hydraulic burrowing in the bivalve Mya arenaria Linnaeus (Myoidea) and associated ligamental adaptations. J Molluscan Stud 63:157-171

> Connell LB, MacQuarrie SP, Twarog BM, Izzard M, Bricelj VM (2007) Population differences in nerve resistance to paralytic shellfish toxins in softshell clam, Mya arenaria, associated with sodium channel mutations. Mar Biol 150: $1227-1236$

> Coughlan J (1969) The estimation of filtering rate from the clearance of suspensions. Mar Biol 2:356-358

Curtis KM, Trainer VL, Shumway SE (2000) Paralytic shellfish toxins in geoduck clams (Panope abrupta): variability, anatomical distribution, and comparison of two toxin detection methods. J Shellfish Res 19:313-319

Emerson CW, Grant J, Rowell TW (1990) Indirect effects of clam digging on the viability of softshell clams, Mya arenaria L. Neth J Sea Res 27:109-118

Fast MD, Cembella AD, Ross NW (2006) In vitro transformation of paralytic shellfish toxins in the clams Mya arenaria and Protothaca staminea. Harmful Algae 5:79-90

Gainey LF Jr, Shumway SE (1988) Physiological effects of Protogonyaulax tamarensis on cardiac activity in bivalve molluscs. Comp Biochem Physiol 91C:159-164

Guillard RRL, Hargraves PE (1993) Stichochrysis immobilis is a diatom, not a chrysophyte. Phycologia 32:234-236

> Guillard RRL, Ryther JH (1962) Studies of marine planktonic diatoms. I. Cyclotella nana Hustedt and Detonula confervacea Cleve. Can J Microbiol 8:229-239

Hall S, Strichartz G, Moczydlowski E, Ravindran A, Reichardt PB (1990) The saxitoxins: sources, chemistry and pharmacology. In: Hall S, Strichartz G (eds) Marine toxins-origin, structure and molecular pharmacology. American Chemistry Society, Washington, DC, p 29-65

Hallegraeff GM (2003) Harmful algal blooms: a global overview. In: Hallegraeff GM, Anderson DM, Cembella $\mathrm{AD}$ (eds) Manual on harmful marine algae. International Oceanographic Commission of UNESCO, p 25-50

Hansen K, King GM, Kristensen E (1996) Impact of the softshell clam Mya arenaria on sulfate reduction in an intertidal sediment. Aquat Microb Ecol 10:181-194

Kvitek RG (1993) Paralytic shellfish toxins as a chemical defense in the butter clam (Saxidomus giganteus) In: Smayda TJ, Shimizu Y (eds) Toxic phytoplankton blooms in the sea. Proc 5th Int Conf Toxic Marine Phytoplankton. Elsevier, Newport, p 407-412

Laby DE (1997). Toxin kinetics and behavioral responses of the surfclam, Spisula solidissima, and softshell clam, Mya arenaria, fed Alexandrium spp. MS thesis, State University of New York, Stony Brook

Landsberg JH (1996) Neoplasia and biotoxins in bivalves: is there a connection? J Shellfish Res 15:203-230

Lewis DE (1996) The relationship between shell microgrowth patterns and physiological energetics of Mya arenaria. MS thesis, State University of New York, Stony Brook

> Lewis DE, Cerrato RM (1997) Growth uncoupling and the relationship between shell growth and metabolism in the soft shell clam Mya arenaria. Mar Ecol Prog Ser 158: $177-189$

MacQuarrie SP (2002) Inter- and intra-population variability in behavioral and physiological responses of the softshell clam, Mya arenaria, to the PSP toxin-producing dinoflagellate, Alexandrium tamarense. MSc thesis, Dalhousie University, Halifax

Maranda L, Anderson DM, Shimizu Y (1985) Comparison of toxicity between populations of Gonyaulax tamarensis of eastern North American waters. Estuar Coast Shelf Sci 21: 401-410

Martin JL, Richard D (1996) Shellfish toxicity from the Bay of Fundy, eastern Canada: 50 years in retrospect. In: Yasumoto T, Oshima Y, Fukuyo Y (eds) Harmful and toxic algal blooms. Intergovernmental Oceanographic Commission of UNESCO, p 3-6

Martin JL, White AW, Sullivan JJ (1990) Anatomical distribution of paralytic shellfish toxins in soft-shell clams In: Granéli E, Sundström B, Edler L, Anderson DM (eds) Toxic marine phytoplankton. Elsevier/North Holland, New York, p 379-384

Martin JL, LeGresley MM, Richard D (1998) Toxic phytoplankton, PSP and ASP toxicity data during the years 1988-1996 from the southwest Bay of Fundy, Eastern Canada. In: Reguera, Blanco RB, Fernandez J, Watt T (eds) Harmful algae. International Oceanographic Commission of UNESCO, p 233-234

Møhlenberg F, Riisgård HU (1978) Efficiency of particle retention in 13 species of suspension feeding bivalves. Ophelia 17:239-246

Morrison CM, Moore AR, Marryatt VM, Scarratt DJ (1993) Disseminated sarcomas of soft-shell clams, Mya arenaria Linnaeus 1758, from sites in Nova Scotia and New Brunswick. J Shellfish Res 12:65-69

Narahashi T, Haas HG, Therrien EF (1967) Saxitoxin and tetrodotoxin: comparison of nerve blocking mechanism. Science 157:1441-1442

Oshima Y (1995) Post-column derivatization HPLC methods for paralytic shellfish poisons. In: Hallegraeff GM, Anderson DM, Cembella AD (eds) Manual on harmful marine microalgae. IOC Manuals and Guides No. 33, UNESCO, p 81-94

Peterson CH, Skilleter GA (1994) Control of foraging behavior of individuals within an ecosystem context: the clam Macoma balthica, flow environment, and siphon-cropping fishes. Oecologia 100:256-267

Quayle D (1969) Paralytic shellfish poisoning in British Columbia. Bull Fish Res Board Can 168:1-69

Quilliam MA, Hess P, Dell'Aversano C (2001) Recent developments in the analysis of phycotoxins by liquid chromatography-mass spectrometry. In: de Koe WJ, Samson RA, van Egmond HP, Gibert J, Sabino M (eds) Mycotoxins and phycotoxins in perspective at the turn of the millennium. Xth Int IUPAC Symp Mycotoxins and Phycotoxins, Guaruia, May 2000, p 383-391

> Retraubun ASW, Dawson M, Evans SM (1996) Spatial and temporal factors affecting sediment turnover by the lugworm Arenicola marina (L). J Exp Mar Biol Ecol 201:23-35

Riisgård HU, Seerup DF (2003) Filtration rates in the soft clam Mya arenaria: effects of temperature and body size. Sarsia 88:415-428

Shumway SE, Cucci TL (1987) The effects of the toxic dinoflagellate Protogonyaulax tamarensis on the feeding and behaviour of bivalve molluscs. Aquat Toxicol 10:9-27

Shumway SE, Cucci TL, Gainey L, Yentsch CM (1985) A preliminary study of the behavioral and physiological effects of Gonyaulax tamarensis on bivalve molluscs. In: Ander- 
son DM, White AW, Baden DG (eds.) Toxic dinoflagellates. Elsevier, Amsterdam, p 389-394

Shumway SE, Barter J, Sherman-Caswell SA (1990) Auditing the impact of toxic algal blooms on oysters. Environ Auditor 2:41-56

Shumway SE, Sherman SA, Cembella AD, Selvin R (1994) Accumulation of paralytic shellfish toxins by surfclams, Spisula solidissima (Dillwyn, 1897) in the Gulf of Maine: seasonal changes, distribution between tissues, and notes on feeding habits. Nat Toxins 2:236-251

Stefano GB, Cadet P, Sinisterra J, Charles R, Barnett J, Kuruvilla S, Aiello E (1990) Functional neural anatomy of Mytilus edulis: monoaminergic and opioid localization. In: Stefano GB (ed) Neurobiology of Mytilus edulis. Manchester University Press, Manchester, p 312

Initial editorial responsibility: Howard Browman, Storebø, Norway; Final editorial responsibility: Hans Heinrich Janssen, Oldendorf/Luhe, Germany
Taylor FJR (1984) Toxic dinoflagellates: taxonomic and biogeographic aspects with emphasis on Protogonyaulax In: Ragelis EP (ed) Seafood toxins. Am Chem Soc Symp Ser No 262, Washington, DC, p 77-97

Trueman ER (1966) The fluid dynamics of the bivalve mollusks, Mya and Margaritifera. J Exp Biol 45:369-382

Twarog BM (1974) 'Immunity' to paralytic shellfish toxin in bivalve molluscs. In: Cameron AM, Campbell BM, Cribb $\mathrm{AB}$, Endean R, Jell JS, Jones OA, Mather P, Talbot FH (eds) 2nd Int Coral Reef Symp, Great Barrier Reef Comm, Brisbane, p 505-512

Twarog BM, Hidaka T, Yamaguchi H (1972) Resistance to tetrodotoxin and saxitoxin in nerves of bivalve molluscs. A possible correlation with paralytic shellfish poisoning. Toxicon 10:273-278

Submitted: October 2, 2007; Accepted: March 4, 2008 Proofs received from author(s): August 21, 2008 